\title{
Conjugated Linoleic Acid: good or bad nutrient
}

\author{
Daniela C Gonçalves ${ }^{1}$, Fabio S Lira ${ }^{2 *}$, Luiz C Carnevali Jr ${ }^{1}$, Jose C Rosa ${ }^{2}$, Gustavo D Pimentel ${ }^{2}$, Marília Seelaender ${ }^{1}$
}

\begin{abstract}
Conjugated linoleic acid (CLA) is a class of 28 positional and geometric isomers of linoleic acid octadecadienoic. Currently, it has been described many benefits related to the supplementation of CLA in animals and humans, as in the treatment of cancer, oxidative stress, in atherosclerosis, in bone formation and composition in obesity, in diabetes and the immune system. However, our results show that, CLA appears to be not a good supplement in patients with cachexia.
\end{abstract}

Conjugated linoleic acid (CLA) is a class of 28 positional and geometric isomers of linoleic acid octadecadienoic [1]. CLA is produced by ruminants, from linolenic (18:3) and linoleic (18:2) unsaturated fatty acids obtained in the diet. Therefore, the natural sources of these substances are dairy products and red meat. Despite of the variety of geometric isomers of linoleic acid, they are present in nature mainly in (18:2) cis-9, trans-11 and (18:2) trans-10, cis-12 forms [2].

Currently, it has been described many benefits related to the supplementation of CLA in animals and humans, as in the treatment of cancer, oxidative stress, in atherosclerosis, in bone formation and composition in obesity, in diabetes and the immune system [3]. However, the most studied effect in relation to CLA supplementation is changes in lipid metabolism not only in animals but also in humans [4].

Although several studies show a beneficial effect of CLA supplementation on immune system parameters, data showing a relationship between CLA and a possible improvement of the are still scarce. The few found work related to CLA supplementation and decrease in muscle proteolysis is directly related to the development of cachexia. Yang and Cook [5] showed that CLA supplementation reduced weight loss, and a reduction of plasma TNF- $\alpha$ in cachetic rats induced by injection of LPS (Lipopolysaccharide - inducing the production of TNF- $\alpha$ by macrophages).

Graves et al. [6] showed that supplementation with CLA in cachetic rats decreased the muscle mass losses,

\footnotetext{
*Correspondence: fabioslira@gmail.com

${ }^{2}$ Department of Physiology, Universidade Federal de São Paulo (UNIFESP),

São Paulo/SP, Brazil

Full list of author information is available at the end of the article
}

due to a decrease of TNF- $\alpha$ receptors in the gastrocnemius muscle. A later study conducted by this group of researchers found that after supplementation with CLA, there was a decrease of the loss of muscle mass, without changing the amount of TNF- $\alpha$ receptor 1 (TNFR1). Thus it appears that this receptor is not actively contributing to the increase of muscle proteolysis in cachexia [6]. Studies by our group showed the effect of CLA supplementation on parameters of lipid metabolism in cachetic rats. Supplementation of CLA was not able to reverse the lipid oxidation in the liver, decreased by cachexia. Moreover, the CLA supplementation promoted greater weight loss and greater accumulation of fat in the liver (hepatic steatosis) and in the plasma [7].

Due to the lack of works explaining the mechanisms which CLA supplementation inhibits muscle proteolysis and the possible role of pro-inflammatory cytokines (such as TNF- $\alpha$ ), more researches are still necessary. Despite these found results, CLA appears to be not a good supplement in patients with cachexia.

\section{Author details \\ ${ }^{1}$ Institute of Biomedical Sciences, University of São Paulo, São Paulo, Brazil. 2Department of Physiology, Universidade Federal de São Paulo (UNIFESP), São Paulo/SP, Brazil.}

Received: 3 August 2010 Accepted: 30 October 2010 Published: 30 October 2010

\section{References}

1. Rayalam S, Della-Fera MA, Baile CA: Phytochemicals and regulation of the adipocyte life cycle. J Nutr Biochem 2008, 19(11):717-26.

2. Banni S: Conjugated linoleic acid metabolism. Curr Opin Lipidol 2002, 3(3):261-6, Review.

3. Silveira MB, Carraro R, Monereo S, Tébar J: Conjugated linoleic acid (CLA) and obesity. Public Health Nutr 2007, 10(10A):1181-6.
Ciomed Central

(c) 2010 Gonçalves et al; licensee BioMed Central Ltd. This is an Open Access article distributed under the terms of the Creative Commons Attribution License (http://creativecommons.org/licenses/by/2.0), which permits unrestricted use, distribution, and reproduction in any medium, provided the original work is properly cited. 
4. Churruca I, Fernández-Quintela A, Portillo MP: Conjugated linoleic acid isomers: differences in metabolism and biological effects. Biofactors 2009, 35(1):105-11, Review.

5. Yang M, Cook ME: Dietary conjugated linoleic acid decreased cachexia, macrophage tumor necrosis factor-alpha production, and modifies splenocyte cytokines production. Exp Biol Med (Maywood) 2003, 228(1):51-8.

6. Graves E, Hitt A, Pariza MW, Cook ME, McCarthy DO: Conjugated linoleic acid preserves gastrocnemius muscle mass in mice bearing the colon- 26 adenocarcinoma. Res Nurs Health 2005, 28(1):48-55.

7. Gonçalves DC: Efeitos do ácido linoléico conjugado sobre parâmetros do metabolismo lipídico na caquexia associada ao câncer. Tese de doutorado, Instituto de Ciências Biomédicas- Universidade de São Paulo; 2010.

doi:10.1186/1758-5996-2-62

Cite this article as: Gonçalves et al: Conjugated Linoleic Acid: good or bad nutrient. Diabetology \& Metabolic Syndrome 2010 2:62.

\section{Submit your next manuscript to BioMed Central} and take full advantage of:

- Convenient online submission

- Thorough peer review

- No space constraints or color figure charges

- Immediate publication on acceptance

- Inclusion in PubMed, CAS, Scopus and Google Scholar

- Research which is freely available for redistribution

Submit your manuscript at www.biomedcentral.com/submit 